\title{
Algo se move: um elogio filosófico-ético à prática do combate como arte e educação
}

\author{
Fernando Hiromi Yonezawa \\ USP- Universidade de São Paulo, Programa de Pós-Graduação em Psicologia \\ (Doutorado), Faculdade de Filosofia, Ciências e Letras de Ribeirão Preto, Departamento \\ de Psicologia e Educação, Ribeirão Preto, SP, Brasil
}

\begin{abstract}
Resumo: Neste trabalho procuramos produzir um elogio filosófico-ético à prática do combate nas Artes Marciais, a partir de nossos anos de prática marcial aliados aos estudos das Filosofias orientais e ocidentais. Traçando uma história crítica das transformações sofridas pelas Artes Marciais, trazemos o conceito de combate como sendo a prática marcial de fortalecimento da vida. Em oposição a isso, mostramos como a noção de luta é resultante da captura que as artes de guerra sofreram por parte dos impérios despóticos. Ademais, demonstramos que o combate se torna prática, ao mesmo tempo, artística e educacional ao visar à produção de um campo de imanência leal ao acontecimento.
\end{abstract}

Palavras-chave: Combate. Arte. Imanência. Máquina de guerra.

\section{Something moves: a philosophical and ethical praise to the combat practicing as art and education}

\begin{abstract}
In this work we tried to produce a philosophic-ethic praise to the Martial Arts' combat practice, based in our years of Martial Arts training accompanied with studies of oriental and occidental Philosophy. Tracing a critical history of the changes happened to the Martial Arts we brought the concept of combat as a martial practice of life empowerment. Opposing this, we presented the notion of fight as a result of the capture that the war arts suffered because of the despotic empires. Besides, we demonstrated that the combat practice is simultaneously an artistic and educational activity, because it aims at the production of an immanence field witch is loyal to the event.
\end{abstract}

Key Words: Combat. Art. Immanence. War-machine.

\section{A travessia das Artes Marciais}

Após alguns anos aliando o treino nas Artes Marciais, especificamente do Hapkido, com os estudos da Filosofia Zen, do Taoísmo e da Filosofia da Imanência de Gilles Deleuze e Félix Guattari, gostaria, neste trabalho, de tecer um elogio filosófico e ético à prática do combate dentro das Artes Marciais. Faremos ainda uma importante diferenciação da prática do combate em relação à noção de luta.

Como sabemos, as Artes Marciais passaram por uma longa travessia até adquirirem seu formato atual. A maioria das artes de combate tem sua história perdida em temos imemoriais, misturada a lendas e feitos heróicos. Sabemos que as Artes Marciais foram sendo sistematizadas no formato que hoje as conhecemos somente a partir, aproximadamente, da metade do século XIX até a metade do século $X X$. Neste trajeto, elas também não estiveram nunca desvinculadas dos conflitos políticos, culturais e religiosos dos povos de que se originaram. Estes caminhos, por forças de diversas naturezas, desembocaram na transformação das Artes Marciais no que hoje se chama de técnicas de luta. Houve, então, alterações pelas quais passaram as artes de guerra, as quais têm relação com a sua transformação em lutas: a militarização, a apropriação das artes marciais por parte dos grandes Estados imperiais. Ao contrário do que se pensa comumente, as Artes Marciais, enquanto artes guerreiras, não têm como conseqüência direta e necessária de sua prática, a constituição de sistemas de luta. Sua estética não remete fatalmente à luta. Esta transformação das Artes Marciais em lutas é resultado tão somente de alguns eventos específicos que estiveram fazendo parte de seu caminho histórico. Destarte, antes de falarmos sobre o combate em si e sobre sua diferenciação em relação à luta, iremos discutir acerca das forças que fizeram parte destas transformações nas Artes Marciais. Trataremos de uma história dos usos que foram feitos das Artes Marciais e das questões políticas e éticas aí relacionadas. 


\section{Os impérios, os nômades e as Artes Marciais: domesticação}

$\mathrm{Na}$ filosofia de Deleuze e Guattari, encontramos o conceito de máquina de guerra, o qual os próprios autores relacionam em algum ponto com as Artes Marciais (Deleuze; Guattari, 1997, p. 79-80). Como sabemos, as artes marciais teriam nascido como técnicas de guerra. Contudo, as artes marciais não pertenciam a esta guerra que hoje conhecemos, realizadas pelos países em conflito, guerra entre Estados. O espírito de guerra, segundo Deleuze e Guattari é algo nascido dos povos nômades, bem como as armas utilizadas (Deleuze; Guattari, 1997, p.50). A máquina de guerra pertencia aos nômades e funcionava, primeiro, como forma de pura expressão do seu modo de existir. A principal questão dos nômades era ocupar os espaços desconhecidos, povoar as terras despovoadas, seguir os fluxos dos elementos que eram vitais (Deleuze; Guattari, 1997, p.102). Cada povo seguia, assim, o fluxo dos elementos que Ihes sustentavam a vida: o fluxo de gnus, ou de alces, os rastros de metais na terra, as presenças de sal. As guerras não traziam a destruição e aniquilamento dos povos como objetivo. A questão era ocupar, mas não destruir. Povoar, mas não esgotar a terra. A guerra não era 0 objetivo final da máquina de guerra nômade (Deleuze; Guattari, 1997, p.103). A máquina de guerra sequer visava à batalha. "O grande guerreiro não é violento. O grande conquistador não combate." (Lao-tzu, 2000, p.155) Ela seria um conjunto de ações com o objetivo de expressar o espírito de guerra, sem que este espírito estivesse já relacionado à batalha e à violência, que reconhecemos na vontade de aniquilamento do outro, presente na guerra entre países. As máquinas de guerra eram constituídas, portanto, por tudo o que permitisse aos nômades ocupar, espalhar-se, seguir seus fluxos vitais e expressar seus modos culturais.

Desenvolviam, assim, símbolos que não tinham função de linguagem escrita formal, metalurgia para a fabricação de armas, bem como a tapeçaria, joalheria e artes de cavalaria, as quais tinham função expressiva, mais do que técnicas e utilitárias. Quer dizer, a máquina de guerra era tudo o que permitia expressar e legitimar as formas singulares de sentir, ver o mundo, pensar, agir - os quais Deleuze e Guattari chamam de afectos (Deleuze; Guattari, 1997, p.72) - destes povos. Formas estas que eram sempre acompanhadas do espírito de guerra, mas não pela guerra de fato. A máquina de guerra é assim chamada por causa da crueza que estes povos enfrentavam na constituição dessa vida de circulação livre pelo mundo.

Destarte, dizem os filósofos que os afectos destes povos eram armas, formas de projetar seu modo de sentir sobre a crueza do mundo como se fossem flechas e lanças. Igualmente, eles expressavam a aridez do mundo em seus corpos, em seu modo de agir e sentir. As armas, neste contexto cultural, eram formas de expressão e uso destes afectos, que recolhiam do mundo e utilizavam em prol da conquista de territórios. Modo de vida que, sim, carregava uma violência, característica do espírito de guerra, da vontade de afirmação de uma vida. Uma violência sanguínea, porém, não sanguinária: agressiva, mas não aniquiladora. Dentro desse contexto, a violência nômade servia para conter a concentração dos poderes e, ainda, para expressar descontentamentos surgidos entre as tribos ou diante dos líderes e sacerdotes (Deleuze; Guattari, 1997, p.113). Além disso, surpreendentemente, dizem os autores que a violência específica da máquina de guerra não é derivação direta da caça, como se costuma imaginar. De forma diversa, esta violência começa com os nômades pecuaristas, que pretendiam acompanhar e se apropriar dos rebanhos, apreendendo seu movimento, sua velocidade, para agregarem-se a ela (Deleuze; Guattari, 1997, p.73-74). Havia uma questão de velocidade de projeção, que a caça primitiva não possuía, pois, nela, o problema era barrar ou parar por completo a velocidade do animal. $\mathrm{Na}$ pecuária nômade, ao contrário, o objetivo era apreender a velocidade, agregá-la para si, seguila para transformar-se nesta velocidade. Assim, da apreensão da velocidade, da projeção do corpo que a apreensão dos rebanhos exige, surge o cavalgar como primeira arma da máquina de guerra e, logo em seguida, as armas de projeção como primeiras formas de expressão desta velocidade, que se sentia tornar-se do corpo. A violência da máquina de guerra, portanto, não tem como afecto a efusão de sangue - da caça e da guerra em si - , mas a velocidade e a projeção, a expansão, o espalhamento centrífugo do afecto (Deleuze; Guattari, 1997, p.73-74). A arma tem seu afecto ligado à velocidade, à projeção. Ela estaria assim, ligada a uma liberdade que a expansão pelas terras produz, a uma "ação livre" (Deleuze; Guattari, 1997, p.76) itinerante. A arma não seria expressão da violência tomada como desejo de destruição, mas de um afecto engendrado na velocidade e na liberdade de expansão, um afecto de outra natureza - uma outra violência, cuja qualidade é não é violar, mas ser veloz. 
As armas eram, portanto, mais uma expressão afectiva do que técnica. Dentro deste contexto específico é que as guerras eram formas de ocupação e contenção de poder. Contudo, para os nômades também aparecia uma questão crucial, a qual foi também condição nevrálgica para a transformação da máquina de guerra numa forma de violência sanguinária, avassaladora. Os nômades conquistavam terras e povos, mas não os destruíam ou aniquilavam. Ao contrário, agregavam-se a estes povos. Mesmo assim, como nômades estariam sempre de passagem, surgia inevitavelmente a questão de o que fazer com os espaços e povos conquistados. Então, esta integração dos nômades aos povos conquistados foi condição de apropriação da máquina de guerra pelos impérios (Deleuze; Guattari, 1997, p.104). É que a dissolução de poderes que a máquina de guerra objetivava incluía os poderes dos grandes Estados imperiais antigos (anteriores à era medieval). As máquinas nômades não aniquilavam, mas também não desejavam poderes centralizados e autoritários, nem dentro de seu próprio povo, nem dentro dos povos que conquistavam. Eles esconjuravam o surgimento de um tipo de Estado, de poder central em seu meio. (Deleuze; Guattari, 1976, p.194) Por isso, somente diante dos grandes impérios despóticos é que a guerra e a batalha se tornavam objetivo da máquina de guerra nômade (Deleuze; Guattari, 1997, p.102). É só diante das ditaduras imperiais que as máquinas de guerra faziam das armas instrumento da guerra, do combate em si. A guerra seria apenas uma ação suplementar da máquina de guerra, uma ação contra a os poderes de Estado despótico. É apenas contra os despotismos e contra o Estado que as máquinas de guerra faziam guerra de fato.

Estes nômades, entretanto, ao se integrarem aos impérios conquistados, comumente tinham sua tecnologia, seus afectos, suas armas e suas expressões também apropriadas por estes Estados imperiais. Era a contrapartida nãodesejada. Deste modo, a máquina de guerra seria distorcida, subvertida numa máquina que objetiva não só a conquista, mas a violência por si só, não apenas a ocupação, mas a destruição completa do outro, a vitória sem o outro. A máquina de guerra e suas armas seriam transformadas em exército, em instituição militar. Ocorre aí a primeira forma de transformação das Artes de guerra em aparelhos de violência, coação e violação dos povos. É só guando os Estados de natureza autoritária, centralizadora e ditatorial se apropriam da máquina de guerra nômade que as artes de combate passam a ser técnicas militares de destruição. O afecto de projeção das armas passa, então, a estar desvinculado do corpo, de sua relação com a liberdade e com a velocidade animal, para ser transformada em arma técnica de destruição.

É a apropriação das máquinas de guerra pelos Estados que faz, assim, as artes guerreiras se transformarem em disciplinas militares de um exército estatal (Deleuze; Guattari, 1997, p.103) e é a partir disso que a guerra passa a ser o objetivo da máquina de guerra e seu afecto passa a ser o de aniquilamento ou a imposição. "Quando um Estado se apropria da máquina de guerra, esta muda evidentemente de natureza e de função, [...]" (Deleuze; Guattari, 1997, p.103) Somente com o despotismo é que as máquinas de guerra passam a ter como fim a batalha. As artes guerreiras seriam domesticadas e transfiguradas.

Conforme os impérios foram crescendo, mais e mais se faziam úteis as artes de guerra; mais e mais se dissolvia a expressividade das máquinas de guerra e, assim, progressivamente crescia a violência e o espírito sanguinário das guerras. Apesar disso, sabemos que os poderes dos soberanos senhores dos impérios eram demasiado frágeis, pois suas terras eram facilmente invadidas, ou roubadas por outros soberanos. O que justificava seu poder eram o misticismo, as divindades, ou a herança familiar e não a existência de um povo ou uma população a administrar. Isso abria precedente para que seu poder fosse tomado a qualquer momento, inclusive por gente traiçoeira, de dentro da corte (Foucault, 2000, p. 279). Dizem ainda Deleuze e Guattari, o Estado nasce na história inteiro já feito, quase milagrosamente, sem processo (Deleuze; Guattari, 1976, p.275). Portanto, os laços que ligam o soberano a seu reino se baseiam em arbitrariedade e violência, justamente por causa desta fragilidade do poder despótico. Este modo de funcionamento dos impérios antigos é o que estará presente também nos impérios modernos.

Evidentemente, não se trata da mesma configuração social e cultural, porém, do mesmo modo de funcionamento, qual seja, o de fazer todo o campo social direcionar-se à centralização do poder num ser absoluto. A população, o campo social, tudo é aferroado ao corpo do soberano (Deleuze; Guattari, 1976, p.251) e é dele que partirá toda lei, todo valor, todo possível. Tudo é coberto por um único e mesmo valor, tudo é "sobrecodificado" (Deleuze; Guattari, 1976, p.252-253), ou seja, o campo social todo é varrido e determinado pelos valores e metas impostos 
pelo imperador e pela formação política correspondente, o Estado. Não falamos aqui de uma história linear, na qual os Estados despóticos teriam se sucedido às formações nômades. Diversamente, os Estados despóticos aparecem em tempos diferentes e em lugares diferentes do mundo. Aparecem na formação imperial egípcia, bem como na China antiga e nos Estados Modernos europeus. Trata-se por isso de uma história fragmentada, descontínua, uma história dos afectos, dos valores, das éticas e políticas. Não uma história dos fatos, mas dos afectos, os quais culminam em práticas de natureza ética bastante diferentes umas das outras. Máquinas de guerra e aparelho de Estado, com sua formação centralizadora, vivem quase que paralelamente. O que acontece é sempre um encontro ou um embate entre o modo de funcionamento da máquina de guerra e o modo do aparelho estatal. Quer dizer, embora os povos nômades tenham quase que desaparecido e apesar de a formação despótica ter sido realmente capaz de cobrir todos os territórios, o modo afectivo e expressivo nômade, sua ação enquanto máquina de guerra permanece viva, atuante mesmo dentro dos Estados, funcionando por lógicas completamente distintas da do Estado.

Mas, o que desejamos deixar claro aqui, é a transformação operada nas artes guerreiras a partir de sua apropriação pelo Estado. Dada a sua fragilidade, os impérios despóticos não podem sustentar seu poder sem que roubem os afectos da máquina de guerra e os vinculem a uma meta, a um fim último, que é a guerra, a batalha. Impor este objetivo é, portanto, fazer a máquina de guerra funcionar em torno da vontade de poder, de manutenção da centralização do poder. Em outros termos, a colocação de uma meta às artes de guerra é o ato político de uma ética baseada na coação, na violência por si só, na sobrecodificação das ações livres que povoam um território. A ocupação e a projeção livre, afectos da máquina de guerra, são transfigurados em dominação e monopólio da circulação das forças do território - afecto da máquina despótica estatal.

Se, por um lado, a violência específica da máquina de guerra se transforma em violência generalizada, por outro, paradoxalmente, a máquina de guerra é assim apropriada somente a partir de sua domesticação, do fechamento de sua riqueza afectiva em torno da colocação de metas. Desta maneira é que as Artes Marciais, em especial as orientais, que possuíam uma forte cultura filosófica e espiritualista, são reduzidas a seu repertório técnico e restritas a sistemas de luta que têm a batalha como meta. As Artes Marciais transformadas em luta são o correlato ético-político da transformação da máquina de guerra em instrumento de violência dos Estados.

Sabemos que a este processo histórico se agregará ainda o advento do capitalismo com a conseqüente transformação no exercício de poder dos Estados. Todo um processo civilizatório se seguirá, de forma a descentralizar o poder do déspota. No entanto essa dissolução do poder virá para pulverizá-lo sobre o território e fazê-lo acumular sobre uma classe certamente mais numerosa, mas igualmente avara $e$ monopolista, a burguesia. Todo um sistema de controle e administração minuciosa da população será constituído. Este processo está certamente ligado à transformação das lutas, desta vez, em esportes modernos. Porém, esta passagem é algo a que não nos deteremos aqui por estarmos ainda construindo um rigor histórico e filosófico que embase esta relação.

Apreendamos apenas a transformação sofrida pelas artes de guerra quando de seu encontro com os Estados imperiais despóticos. Esta transfiguração é de extrema importância para a diferença ética e conceitual que estabeleceremos, a partir daqui, entre arte de combate e luta.

\section{O Combate e a Luta: uma diferenciação ética}

Assim, trazemos aqui a noção de combate como distinguível ética, política e filosoficamente desta prática estatizada da luta. Como forma também de combate, esboçamos aqui um conceito de combate que possa trazer nova potência às Artes Marciais, talvez, de modo a avivar um pouco de sua força enquanto máquina de guerra.

O combate não é a guerra, não é a batalha. Assim como na máquina de guerra o objetivo das armas não é a guerra. O objetivo das Artes Marciais não é o combate, mas não porque o combate seja irrelevante. É que o combate não é um fim, senão um processo. $O$ combate não é princípio - o que seria o mesmo que ser o fim mas justamente um caminho, um Do. As Artes Marciais possuem o combate muito mais como um de seus modos expressivos, um de seus afectos: como seu caminho e não como seu objetivo. Portanto, se as Artes Marciais não se restringem ao combate elas, contudo, não podem existir sem ele. O combate, assim, é um momento das Artes Marciais, é um momento que acontece, que nos acontece, acontece através de nós. Destarte, ele pode não se confundir com o confronto frente a frente em si - kumite, kiorugi, 
shiai -, mesmo que seja este, muitas vezes, o momento do combate. Seria este o sentido de $o$ verdadeiro combate não é com o inimigo, como dizem os mestres de Artes Marciais? O combate é um tempo, um momento que passa, acontece. O combate 'verdadeiro' não se vê, ele passa por nós. É real, mas transparente, cristalino. Dentro das Artes Marciais o combate não é a essência, mas uma 'excência', ou seja, é algo que se extrai das artes de guerra, como se tira diversos remédios de uma erva. Isso porque o combate se diferencia completamente da luta. Uma Arte Marcial não é nunca um sistema de luta. Ela se transforma num tipo de luta quando fica restrita a seu uso pelo Estado, pelo espírito de centralização de poder. A luta é um supérfluo, ela não faz mal a ninguém, pois é ética, política e socialmente inofensiva. Ela não tem a potência afectiva da máquina de guerra. Quer dizer, ela se baseia num afecto frágil, que recorre à violência para se sustentar, a vontade de poder, dominação do outro e aniquilamento deste.

O combate, ao contrário é um grande perigo, nele, algo importante está em jogo. O combate vem sempre em defesa da vida, de uma vida. Um lutador pode morrer sobre o tatami e, mesmo assim, não ter passado por isso que chamamos aqui de combate. É que o combate é, na verdade, inútil, mas essencial, vital. O combate é um jogo intenso em que o que corre risco é uma vida, quer dizer, é uma linha de vida, um sopro vital que entra em combate para se manter de pé, para se manter ereto.

No combate, se defende um espírito, nunca um ponto, um nocaute, uma taça, um campeonato, uma pessoa, um ego, um indivíduo. No combate, o que corre risco e aquilo que se defende é invisível, é uma sensação, um pedaço de vida que inunda o corpo de quem está no combate. Pode ser medo - um medo qualquer -, pode ser a dor, pode ser a força, pode ser uma potência, a vontade de potência. Por isso, no combate, o que se defende é alguma linha de vida, é alguma coisa muito delicada, muito sutil, que é também essencial à vida. Quando alguém entra no combate, entra com algumas dessas sutilezas que o faz querer, simplesmente querer. Querer sem objeto, sem objetivo, força pura de afirmação, intensa positividade diante do mundo. São potências, forças sutis que têm um vigor assustador, terrível, grandioso. Potência, por definição filosófica, é a capacidade de afetar e ser afetado pela vida, é o aumento da capacidade de agir (Deleuze, 2002, p.103). Assim, todo afecto é uma potência. Alguns guerreiros japoneses entendiam bem essa sutileza quando admiravam uma cerejeira florida e, ao mesmo tempo, eram capazes de ser ferozes combatentes em uma guerra. É que, no combate, o que estava em jogo era o mesmo que se fazia presente nas pétalas róseas da cerejeira, a força do vivente, que é assustadoramente forte e, simultaneamente, delicada e sutil. No combate, trata-se é de defender uma potência, algo que vive no artista marcial, mas que não lhe pertence, está passando por ele - pertence ao mundo, à vida. Vive através dele e tem a força de produzir toda uma vida, um universo, mas não é sua propriedade. Forças públicas, forças coletivas e comunitárias da vida. Por isso é que o combate é algo perigoso, mortal, ainda que não machuque ninguém e que ninguém saia fraturado ou nocauteado. O combate tem vontade de potência, não de poder.

A Arte Marcial, enquanto arte do combate é a arte de defender as coisas que existem de profundamente essenciais na vida, mas que são inomináveis, inumeráveis, imperceptíveis, quase inidentificáveis, porém, reais, viventes, respiram em nosso peito, em nosso corpo, nos alimentam e vivem de nosso ar. Imperceptível, mas consistente, legítimo, invisível, mas real; transparente, mas concreto. São essas forças delicadas que se trata de manter vivas no combate - forças que só é possível acessar através de uma espécie sofisticada sensibilidade, ou intuição. É a feroz força que a vida move para produzir uma flor de sakura, ou um ovo de pássaro; a mesma força que passa por nós, não é de nossa propriedade, mas cabe a nós cuidar e cultivar. Tal é a razão de Confúcio dizer que somos a ponte entre o céu e a terra. Esta é a força envolvida no combate e que as Artes Marciais nasceram para defender. Fluxo de vida que passa por nós e nos acontece minuto a minuto. Talvez seja isso que se chame de $K i$, ou Ch'i.

Por isso, o combate é inútil - diferente de fútil. Inútil ao Estado, às empresas, ao mercado. Inútil para o poder. Diante disso é que o combate é inútil e, ainda assim, essencial à vida. Inutilidade provinda das máquinas de guerra nômades. Entretando, não é fútil. O combate serve, não a um exército, nem a um império, mas à vida, ele vem para defender a vida. As Artes Marciais existem para fortalecer a vida, esta vida sutil e potente que passa por nós e que nos bota de pé. Ora, não seria a defesa dessa vida que destaca a versão histórica do nascimento das Artes Marciais, que atribui aos monges chineses a criação dos movimentos marciais como forma de manterem-se fortes?

Deste modo, o combate pode acontecer em qualquer lugar, depende apenas da maneira 
como é feito, do modo de relação que se estabelece com as Artes Marciais, do uso que se faz dela e de como se as ensina. Depende de que tipo de corpo e espírito se alimenta na prática e no treino do combate, ou seja, depende da natureza da ética envolvida. Assim, o combate que treinamos em Artes Marciais seria uma espécie de laboratório ou condição artificial e experimental de produção daquele combate que a vida realiza diariamente em nosso corpo, no mundo, na natureza, de forma discreta e paulatina. Não estaria nisso o grande perigo e potência de um combate? Ora, se ele alimenta e fortalece, no espírito e no corpo do artista marcial essas intensas e vibrantes forças de vida, não estaria também criando, nestas pessoas, forças capazes de mudar modos de ver, viver, agir, pensar e relacionar-se com o mundo?

Portanto, entre o combate e a luta existe uma diferença ética fundamental. No combate, trata-se de fortalecer a vida, de defendê-la alimentando-a. Fortalece-se a vida no artista marcial, a sua coragem. O combate é uma prática de uma ética que vem em prol de tornar vigorosas as forças de vida. Neste sentido, o combate é mortal, põe algo da vida em risco, ainda que ninguém morra de fato. Na luta, ao contrário, mesmo que todos saiam feridos ou mortos, nada morre ou se faz viver, há apenas um joguete que deseja vencer ou aniquilar o outro. As lutas são subservientes a muitos usos violentos. Por isso, em cada treino, em cada pupilo, no momento de um combate, é preciso se perguntar que tipo de forças, que natureza de espírito se está alimentando. A serviço de que se está trabalhando? Tal é a tarefa ética e também educativa da arte do combate: diferenciá-lo do simples exame da técnica ou do poder de destruição dos golpes. Tarefa de tornar os movimentos marciais e seu intenso jogo combativo numa forma de fortalecer e criar forças de vida.

O combate deve servir à vida, e não servir-se dela: o combate não deve servir a nada que venha a se servir da vida. Assim, a dinâmica do combate, como forças de vida agitando-se para se manter de pé, precisa poder ser transportada para o cotidiano, precisa ser ele mesmo, o próprio cotidiano. Mas não à maneira referida pelas grandes multinacionais: 'torne cotidiana a competitividade, treine-a no Karatê e traga-a para o sucesso da empresa, para a relação com seu colega, ganhe dinheiro com isso'.

\section{A tarefa última do combate: arte e educação}

Deste modo, temos aqui um primeiro aspecto do combate enquanto arte: ele é inútil, como toda arte. Ele não serve para nada que não seja a expressão de um afecto, o qual, no caso, é a potência de uma vida. Isso é algo que os arqueiros do Kyudo demonstram compreender bem, assim como os calígrafos do Shôdo ${ }^{1}$, cujos kanji não são comunicativos, não têm função técnica, apenas artística e expressiva. É em sua inutilidade que o Kyudo expressa seu mais profundo espírito (Herrigel, 1975, p.16). Por isso, se, quando se inicia um combate, se inicia com um fim, então já se começa mal... Quer dizer, se se começa um combate com um objetivo, então já se está enfraquecido, já se está é lutando e não combatendo. Lutar é fazer sobressair o Estado, é estatizar o combate impondo-lhe uma meta. Assim, sirvamo-nos, aqui de mais algumas conceituações filosóficas de Deleuze e Guattari.

Para seguirmos nesta vereda filosófica do combate, então, trazemos os conceitos de imanência e de plano de imanência. A imanência é um modo de posicionamento e de manejo da realidade, é um modo de estar na realidade. Em primeiro lugar, este modo imanente se opõe ao modo transcendente, o qual entende a realidade como já dada, inteira feita, pronta, sem alterações. Ou seja, no modo transcendente de se posicionar na realidade, existe um conceito de realidade, uma idéia pronta acerca dela, a qual vem à priori e é colada sobre ela, restringindo suas possibilidades. A transcendência hierarquiza a realidade, fragmenta-a, pois trata certas partes dela como primordiais, mais importantes, ancestrais, colocando estas partes acima de outras. Assim, o modo de um imperador ou de um déspota se relacionarem com o mundo é exatamente transcendente. Toda transcendência é autoritária. Sempre que se cola um ideal primordial ou um modelo sobre a dinâmica múltipla e imprevisível da realidade, se está na transcendência. Na imanência, por outro lado, se trata a realidade como um plano, uma superfície. Imanência significa 'estar ao lado', quer dizer, na imanência, tudo o que compõe o real está junto, num mesmo plano, interconectado, sem que nenhuma parte seja causa primeira ou última das coisas; todas as coisas seriam causas diretas ou indiretas umas das outras.

\footnotetext{
${ }^{1}$ Kyudo, a arte do arco e flecha Zen. Shôdo, a arte Zen da caligrafia, na qual os ideogramas são escritos com pincel sobre papel de fibra de arroz utilizando-se tinta de carvão. $O$ objetivo é expressar afectos através das linhas. Por isso, muitas vezes, os ideogramas são deformados, tornados praticamente ilegíveis, mas portadores de expressividade.
} 
Também se diz que a realidade imanente é um rizoma, tal qual a espécie de raiz que algumas plantas apresentam. Neste tipo de planta as suas raízes se interligam quase infinitamente, formando um vasto plano, capaz de cobrir uma imensa extensão, sem que se saiba onde começa e termina cada talo, sem que se saiba de onde brotou e onde terminará o organismo todo. No rizoma, qualquer parte pode ser conectada a qualquer outra, a partir de qualquer ponto. O rizoma pode ainda começar a se multiplicar a partir de qualquer lugar, espontaneamente. (Deleuze; Guattari, 1995, p. 15) Assim, a imanência trata a realidade como um campo aberto, nunca acabado, mas sempre sendo produzido: a realidade se cria a si própria o tempo todo - movimento de autopoiese (autoprodução). Tudo o que compõe a realidade está em movimento, se transformando, criando, fazendo novas interconexões e criando novos elementos e formas de vida. Assim, na imanência, nada nem ninguém é mais importante, assim como nada nem ninguém tem mais poder de criar ou realizar, todos são igualmente potentes. Tudo está num mesmo plano, lado a lado, quando se está na imanência. Quer dizer, entre imanência e transcendência existe uma diferença ética fundamental.

Contudo, na imanência, os movimentos são tantos, há sempre tal multiplicidade de elementos, forças, movimentos e transformações acontecendo que aí se constitui um caos absoluto. Tal caos, a rigor, sendo considerado a partir da dinâmica das forças e das transformações da realidade, não possui formas e modelos, apenas linhas de força, passagens, velocidades, potências. Assim, nesta superfície tão movimentada, em que tudo se confunde com tudo, é preciso estabelecer um traçado, um território, uma ilha territorial que consiga oferecer um mínimo de possibilidade de manejo da realidade. Tal traçado é chamado, então, plano de imanência. Quer dizer, realiza-se um crivo no caos, um recorte ou um mapeamento (Deleuze; Guattari, 1992, p. 59), que vai permitir manejar, caminhar por esta realidade sem ser sugado ou arrastado pela intensidade de sua movimentação e multiplicação. Estes conceitos de imanência e plano de imanência poderiam muito bem ser relacionados à noção de vazio do Zen, ou ao Tao do taoísmo, já que ali, neste rizoma, nada possui nomes, nem há formas, pessoas ou seres individualizados. Todos se igualariam enquanto forças de composição da realidade. Iguais em potência e, no entanto, diferentes em natureza. Haveria um vazio, mas um vazio de formas e estruturas visíveis, haveria apenas 0 imperceptível, seria um vazio-cheio, povoado de inumeráveis forças e movimentos, invisíveis, porém reais.

Pois bem, consideramos que, num combate, a grande tarefa seria a de lidar com este caos de possibilidades e movimentos que potencialmente poderiam acontecer e que já povoam o vazio. Um primeiro traçado neste caos, o plano de imanência seria o plano liso e vazio do tatami. O tatami seria um vazio-cheio, Tao, em que todas as forças e possibilidades do combate já vivem potencialmente. $\mathrm{O}$ combate em si seria um grande vazio, cheio de potências invisíveis, fervilhando caoticamente. No caos, no vazio, deve-se desenhar um risco e o primeiro risco é o tatami, o plano sobre o qual as forças do combate irão correr e se transformar. Um vazio plano, largo, todo preenchido por todas as infinitas potencialidades do combate, nenhuma mais provável ou mais previsível que outra. Um plano sem espessura, apenas com superfície. O primeiro desafio do combate, então, seria o de se fazer presente no espaço liso e caótico do tatami sem ser sugado e esfacelado por ele e por sua multiplicidade de potências invisíveis. Fazer-se presente também, por outro lado, sem estar vestido de transcendência, de idéias à priori, de objetivos prontos. Portanto, ao se entrar no combate se está entrando no plano de imanência, se está propondo, a si mesmo, que se perca o nome próprio, se dissolva sua forma bem acabada e se encare o risco de ser completamente esfacelado pelas inúmeras forças e possibilidades que compõem o combate. No combate não se pode mais ter identidade, não pode haver forma, idéia alguma como princípio. No combate não se está mais no comando consciente das forças, há muito mais forças acontecendo que a nossa consciência ordinária é capaz de controlar. Por isso o combate carrega uma crueza - uma crueldade -, um afecto muito próxima da máquina de guerra nômade. 0 combate é impiedoso, cruel, sem que haja, por outro lado, injustiça ou poder.

Amir Klink (Klink, 2000), ao dar a volta ao mundo, num barco a vela, sozinho, circundando a calota antártica, dizia que, para uma viagem como a dele, eram necessários preparo e planejamento extremamente rigorosos, mas o apego a esses planos durante a viagem seria fatal, catastrófico. O apego aos planos poderia levá-lo à morte. Sentimos que as viagens de Amir Klink sejam de verdade, isto é, há nelas uma delicada e intensa força de autenticidade, ímpeto de afirmação de uma vida. De verdade quer dizer sincero, leal à intensidade da vida. Amir Klink não traiu a imanência só porque planejou e, por outro 
lado, planejou bem para que não fosse fisgado dolorosamente pela transcendência, pela idealização.

Assim, na Arte Marcial, na arte do combate, o intenso treino, o lapidar das técnicas não tem fim último, senão o de preparar um corpo e um espírito que sejam bons condutores, bons lugares de acontecimento das forças do combate. Treinamos não para vencer, mas para resistir à intensidade do combate, para sermos bom cavalo para que as potências do combate possam cavalgar em nós. Devemos ser charneira para a efetivação do combate. Quer dizer, no combate não somos quase nada, apenas lugar de passagem, dobradiça entre a vida e a surpresa, entre o imprevisível e a potência. No caso de Amir Klink, o espírito navegante flutuante e fluido transpassou os planos, jogando-os no próprio processo. O processo caotiza o plano e embaça o lugar que se pensava ser o início. Amir Klink é um artista do combate, não pela necessidade, pelo fato de estar no mar. Pelo contrário, habita o mar porque se afeta pela fluidez da atividade combativa, a qual não se efetua de outra forma senão no próprio movimento incerto da água. A água não é mais por aonde se vai, ela é aquilo em que se transforma o tempo todo. A água é um paradoxo: o tempo todo muda de forma, de estado, sem, entretanto, deixar de ser água. A água dobra-se à maneira das pedras que vence, tornando-se um pouco, ela própria, as pedras, as curvas, as quedas: a água se torna potencialmente pedra. "Se cai numa garrafa, se torna a garrafa" ${ }^{2}$; se encontra uma parede, fissura-a lentamente até estourá-la. Daí o conceito taoísta de $Y u$ - água -, presente no Hapkido - fluidez, impenetrabilidade, continuidade, flexibilidade, capacidade de transformação, penetração, infiltração. A água é uma impenetrabilidade paradoxal. A água está sempre se diferenciando de si própria, tal deve ser o modo de o artista marcial se colocar em combate.

Desta maneira, vemos o combate como arte aquática, como arte de nadar, a arte de aliar-se à água. Combater é navegar, arte de acompanhar a água, ser água em potencial - combate é a arte Yu. "A água favorece todas as coisas e não exclui nenhuma." (Lao-tzu, 2000, p.27) Por isso, seu método deve ser a estratégia-sem-estratégia, ou o caminho-sem-caminho. "O que carece de forma penetra o impenetrável. Por isto conheço o valor da não-ação." (Lao-tzu, 2000, p. 105) Todo Do nas Artes Marciais deve ser um caminho cujo fim inexiste. Por isso, o combate não está no fim,

\footnotetext{
${ }^{2}$ Bruce Lee em uma entrevista.
}

nem no começo, ele é o meio, a passagem do Do. E não seria esse o sentido mais profundo da expressão caminho do meio que o budismo, inclusive o Zen, utiliza? O caminho do meio não é o meio termo, mas a passagem: segui-lo é colocar-se sempre na travessia, na passagem, tomando o combate como esta travessia sem objeto final, caminhada sempre em processo. Não é possível estar no meio termo, sempre se está inteiramente do lado do processo, de coração inteiro no caminho. O plano para o combate deve ser encontrado, por tal razão, no meio do caminho, no próprio processo que é o combate. Este é o sentido de Do - caminho - nas Artes Marciais. Assim, no trecho "Por isto, o sábio, ainda que viaje todo dia, nunca esquece o princípio do caminho" (Lao-tzu, 2000, p.69) do Tao Te King, 'o princípio do caminho' não quer dizer 'o começo' do caminho, mas o princípio que se encontra no caminho, através dele, princípio que pertence ao caminho.

Porém, a questão importante para a arte do combate é que, apesar de se colocar, de certo modo, à deriva sobre um plano de imanência, o artista marcial deve ser capaz de produzir uma absoluta precisão. Daí a expressão do Kendo: um corte, uma vida. Ou ainda, derrubar com um golpe apenas, do Karatê. É que, no combate, o artista marcial deve estar tomado de imanência, deve se colocar logo ao lado das forças que povoam o tatami, de modo a interceptá-las profundo Jeet Kune $D o^{3}$-, ou até, ser interceptado por elas, dando-lhes passagem, servindo-se de cavalo para que cavalguem. Estar ao lado é ser parceiro das forças, ser leal a elas. O artista marcial deve estar "à espera do acontecimento" (Deleuze, 1969, p.133) para que, no momento certo, seja capaz de dar vazão à energia, projetando o golpe perfeito - profundo wu-wei, agir pelo não-agir. Não o golpe mais destruidor, mas aquele mais forte, porque é desferido com precisão, no lugar certo, no tempo ótimo do combate, com a velocidade de uma flecha. Por isso o Jeet Kune Do enfatiza a velocidade como pivô da potência, cuja efetivação depende, primeiro, do relaxamento dos músculos, da mente e de todos os membros. Estar à espera implica em pôr-se aberto a nãoagir, deixar-se despido da obstrução de fluxo trazido pelo retesamento muscular, colocar-se à deriva. Tencionar-se acarreta num fechamento de possibilidades, posto que a contração é uma forma de acúmulo, embotamento ou represamento de energia: é uma espécie de avareza. No combate, a velocidade faz a força,

\footnotetext{
3 Sistema criado por Bruce Lee, que é traduzido como "Caminho do Punho Interceptador"
} 
mas a força não é do músculo: espera-se pelo acontecimento e é dele que vem a força. Tal é outro aspecto artístico do combate: ser preciso para com as forças imanentes advindas do plano vazio do tatami. E precisão não é sobredeterminação, não é coação dos fluxos, mas lealdade para com o tempo do combate, para com as potências do inesperado, do insuspeito. Neste sentido é que, no combate, não é o artista marcial que golpeia e projeta seus membros, como armas de uma máquina de guerra. O combate não conhece pessoas, técnicas prontas e formas, ele só conhece a charneira que melhor dará vazão ao golpe. No combate, algo se move, algo golpeia, "algo atira" (Herrigel, 1975, p.63). Não é a pessoa do artista marcial que o faz, mas algo nele e que por ele passa que faz. O ego, a identidade, devem ser dissolvidos, arrastados pelas forças do combate. O ego é o Estado em nós, ele traz transcendências ao invés de fazer colar o espírito do artista marcial à superfície do combate. “Quando você diz 'eu' respiro, o 'eu' está a mais. Não há um você para dizer 'eu'. O que chamamos 'eu' é apenas uma porta de vaivém quando inalamos e exalamos." (Suzuki, 1994, p.27) O artista marcial precisa, deste modo, diferir de si próprio, dobrar-se sobre si, afectar-se a si próprio. Ele está nu, órfão, conta apenas com a imanência, com seu corpo. Com isto, Karatê-do o caminho das mãos vaziais - ou Taekwondo - o caminho dos punhos e dos pés - ganha um sentido mais profundo, um sentido ético, ligado à forma como se vive. Talvez seja desta crueza ou nudez despida de ego, que nos venha a sensação de, quando de um bom combate, não termos sido nós mesmos a nos movimentarmos no tatami. No bom combate é como se nos ausentássemos e, paradoxalmente, é como se estivéssemos o mais presente possível paradoxo que a imanência nos faz sentir. Dobramos-nos, vergamo-nos sobre nós para nos transformarmos - um intenso rigor das Artes Marciais.

Desta maneira, o combate passa a ser uma "arte da superfície" (Deleuze, 1969, p.9) em que não há mais as alturas dos objetivos transcendentes, pré-concebidos, só há o plano liso e vazio do tatami, diante do qual o artista marcial se coloca aberto, à disposição, para que seja capaz de deflagrar o acontecimento, o golpe da precisão. "[...] às vezes tinha a sensação de não respirar, mas de ser respirado." (Herrigel, 1975, p.34) Pelo mesmo motivo, o artista marcial, quando golpeia, não golpeia o outro, mas é golpeado. "No fundo o atirador aponta para si mesmo e talvez em si mesmo consiga acertar."
(Herrigel, 1975, p.16) O bom tiro, o bom golpe é aquele que surpreende o próprio combatente. "Somente se o próprio arqueiro se surpreender com a saída da flecha, é que o tiro sai suavemente, [...], sem que se abra a mão intencionalmente." (Herrigel, 1975, p.40) A potência é sempre um insuspeito que nos assalta, toma nosso corpo emprestado para passar. Seria este, então, o sentido de você mesmo é seu verdadeiro inimigo? Seria isso o objetivo dos Shinobi ${ }^{4}$, atacar segundo a potência do invisível? Um devir-mulher do artista marcial. Ora, no combate, a guerra se trava não entre o artista marcial e o outro, mas entre ele e aquelas forças que nele próprio atuam fazendo-o correr o risco de subir à transcendência, à vontade de um objetivo final. Só quando o artista marcial cria uma meta para o seu combate, é que ele próprio se faz pego e, assim, corre o risco de ser derrubado.

"Quando você tenta obter algo, sua mente começa a divagar por outros lugares. Quando você não se ocupa em obter algo, sua mente e seu corpo permanecem juntos, presentes onde você está." (Suzuki, 1994, p.25) No combate, os golpes devem ser, portanto, "objetosacontecimentos" (Deleuze, 1969, p. 139), reenviados à superfície vazia do combate. Por isso é que existe o conceito-experiência Zen de mushin, não-mente. Quando se cria uma meta ao combate, o artista marcial cria aí uma mente, um Estado e, então, seus movimentos estão fadados a serem vãos. Não é mais a intuição de um artista à espreita do movimento mais preciso que passa a funcionar, mas a mais traiçoeira racionalidade. A mente polui a intuição do artista marcial, intuição que deve ser transparente, sensível, ágil. "Muita mente, Sr. Algren! Muita mente!" 5 Assim, poderíamos dizer, mushin é o equivalente Zen do conceito de imanência.

O artista marcial deve mover-se sem que haja sequer um fio de cabelo que separe o movimento, o corpo e o espírito. Tudo deve estar tão junto que não haja mais divisão. "[...] nem dois, nem um. [...] Se você pensa que seu corpo e mente são dois, está errado. Se pensa que são um, também está errado." (Suzuki, 1994, p.23) Na arte combativa os movimentos devem acontecer, o combate deve nos acontecer, precisamos que os golpes partam "[...] como a chuva que cai do céu" (Herrigel, 1975, p.12), esvaziados de intenção, carregados de um tipo muito singular de

\footnotetext{
4 Guerreiros japoneses, treinados em clãs secretos, costumavam agir aproveitando o escuro da noite ou disfarçando-se. São grosseiramente chamados ninja.

${ }^{5}$ Diz o jovem samurai ao aprendiz ocidental de esgrima japonesa, no filme "O Último Samurai".
} 
inocência. A colocação de uma meta ao combate é o que o transforma em luta, forma estatizada pelos impérios. Meta é transcendência. Isso porque, quando há meta, existe ego e, onde existe ego, há uma intenção facilmente apreendida pela vontade de poder, característica dos déspotas. A questão, porém, não é suprimir a vontade, mas que a vontade não seja meta e sim movimento imanente. É este desejo com metas que o budismo trata de suprimir, por crer ser o princípio para o sofrimento. Apesar disso, alertamos, o problema não é a vontade, mas a presença da meta, do ego. A vontade em si não tem objeto, ela é uma força de vida, de ação livre, como os nômades. Se as lutas visam à vitória e o impor-se sobre o outro, o combate visa, por outro lado, apenas o acontecimento, que se processa em nós.

\section{Conclusão: marcializar o combate}

Desta maneira, vemos que a arte do combate, é arte de mergulhar no caos invisível e imprevisível para dele se sair transformado. A questão do combate é resistir ao caos, não contêlo ou controlá-lo, mas tirar força dele para fazê-lo jogar em favor de uma potência. Tentar controlar o imprevisível é morrer, é matar o combate, matar a si próprio. Ser gentil para com o imprevisível, está aí o sentido de Ju, suave, do Judô e do Jujitsu. Também este é o sentido do laido ${ }^{6}$, arte de enfrentar o imprevisível. Como dissemos, o combate é sempre mortal, porque há algo de essencial à vida em risco. Nas lutas, pelo contrário, já não há nada que se possa matar, porque a colocação de uma meta já nos tirou a vida, o Estado em nós já nos matou muito antes.

Quando em combate, o artista marcial se coloca em processo, o que faz com que toda a prática da Arte Marcial seja já, de algum modo, um combate, ou seja, só se está sempre em processo, em transformação. Por isso os katá,poosae e hyung - rotinas - são já combate também. Esta seria, talvez a tarefa educativa das Artes Marciais. A questão não é militarizar o pupilo, mas marcializá-lo, torná-lo potente, aguerrido ao invés de guerreiro: treino árduo para que esteja preparado para dar passagem às intensas e pujantes forças que povoam 0 combate. Educar o artista marcial na arte do combate é torná-lo forte para os problemas essenciais da vida, é ensiná-lo a manter de pé aquilo que o faz vivo, forte. Esta é a razão dos mestres dizerem a arte marcial é para melhorar a

\footnotetext{
${ }^{6}$ Prática que é parte da arte da esgrima japonesa e que é traduzida com imprecisão como "Arte de Desembainhar a Espada", pelo fato de sua técnica se basear no saque $e$ embainhar do sabre.
}

autoconfiança: educar para a potência. Isso transforma o combate numa forma sofisticada e delicada de ascetismo, cujo trabalho não é o de anular-se a si próprio - como no ascetismo cristão - mas o de avivar-se, tornar-se lúcido, transparente. Por isso a palavra iluminação, satori, do budismo. A educação do combate se faz não no sentido de vencer o outro, mas de crescer com o outro. Deste modo, o outro deixa de ser um oponente, para se tornar um parceiro, alguém que está logo ao lado, para realizar junto esta difícil arte da imanência.

Por isso, existe uma paz paradoxal nas Artes Marciais, que faz das armas um meio de obter paz (Deleuze; Guattari, 1997, p.83), a qual, entretanto, não é a paz ambígua imposta pelos impérios. Toda ditadura diz haver paz em seu povo, mas toda diferença é tratada como crime e, no limite, sofre reais bombardeios. A diferença é literalmente destruída e o outro é sempre um oponente, um inimigo. Paz perversa que isola e torna solitárias as pessoas. Esta é, portanto, a diferença ética que pode fazer do combate uma séria arte do Budô, ou reduzi-lo a sistemas de luta. É esta a encruzilhada ética e filosófica que difere o Budô de um sistema de técnicas; é o que faz do combate uma arte e um aprendizado para a vida e não um meio de evacuar a agressividade, como dizem alguns psicólogos de pensamento obsoleto. Por isso, mesmo o Aikido, que não possui torneios, é pura arte de combate, é um potente Budô.

Se na história da arte marcial foram a instituição militar e o Estado que dela se apropriaram, de maneira diversa, esta história não é uma fatalidade, não é a única possibilidade, não é o futuro. Além disso, esta história da captura da máquina de guerra pelos Estados não é exatamente uma linearidade, uma evolução. Os processos sociais e políticos - a estatização, a militarização - aconteceram paralelamente, sem que o advento de um implicasse no desaparecimento de outro. Quer dizer, eles todos, inclusive a máquina de guerra, continuam atuantes em nossa contemporaneidade. É ao mesmo tempo que a máquina de guerra se transforma em propriedade do Estado e em luta. Desta forma também é que o combate se torna vital: ele está sempre sob o risco iminente de ser estatizado - e estatizado por nós próprios. Se pensarmos no sentido da máquina de guerra, podemos dizer que, na história, o combate e as Artes Marciais foram des-marcializados. Por isso, é preciso despoluir as Artes Marciais da instituição militar. O combate é coisa da máquina de guerra que avança para deixar viver e não simples prática que nos mantém saudáveis para, 
no limite, extorquir a vida em nós. Presença, portanto, de um limiar político do combate, que pode muito bem extrapolar o território dos sistemas marciais e ser levado ao nível dos problemas de ordem pública - grande periculosidade que a máquina marcial apresenta para o Estado, potência que a luta não possui. Combate é a arte de fortalecer a intensidade da vida. A vida, afinal, é "Viver combatendo", dizem as Madres de Plaza de Mayo. ${ }^{7}$

\section{Referências}

\section{DELEUZE, G. Espinosa - Filosofia Prática. São}

Paulo: Escuta. 2002.

DELEUZE, G. Lógica do Sentido. São Paulo:

Perspectiva. 1969.

DELEUZE, G. \& GUATTARI, F. Mil Platôs Capitalismo e Esquizofrenia. v. 1. Rio de Janeiro: Editora 34. 1995.

DELEUZE, G. \& GUATTARI, F. Mil Platôs Capitalismo e Esquizofrenia. v. 5. São Paulo: Editora 34. 1997.

\section{DELEUZE, G. \& GUATTARI, F. O Anti-Édipo -} Capitalismo e Esquizofrenia. Rio de Janeiro: Imago. 1976.

FOUCAULT, M. Microfísica do Poder. Rio de Janeiro: Graal. 2000.

\section{HERRIGEL, E. A Arte Cavalheiresca do}

Arqueiro Zen. São Paulo: Editora Pensamento, 1975.

KLINK, A. Mar Sem Fim, São Paulo: Companhia das Letras. 2000.

LAO-TZU, Tao Te King - O Livro do Sentido e da Vida, Curitiba: Hemus, 2000.

SUZUKI, S. Mente Zen, mente de principiante. São Paulo: Palas Athena, 1994.

Esse artigo foi apresentado em Sessão Temática no VI Congresso Internacional de Educação Física e Motricidade Humana e XII Simpósio Paulista de Educação Física, realizado pelo Departamento de Educação Física do IB/UNESP Rio Claro, SP de 30/4 a 03/5 de 2009.

\footnotetext{
7 Lema dos cartazes de protesto das mães argentinas que tiveram seus filhos raptados e mortos durante regime militar. Estas mães construíram um potente movimento popular que teve, entre suas conquistas, a criação de uma universidade popular. O movimento destas mães continua ativo em sua militância até hoje.
}

Endereço:

Fernando Hiromi Yonezawa

R. Clóvis Bevilaqua, 550 - apto. 31-C4

Campinas SP Brasil

13073-021

Telefone: (19) 8155.0612

e-mail: fefoyo@yahoo.com.br

Recebido em: 10 de fevereiro de 2009. Aceito em: 03 de abril de 2009.

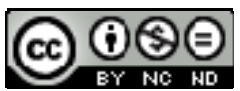

Motriz. Revista de Educação Física. UNESP, Rio Claro, SP, Brasil - eISSN: 1980-6574 - está licenciada sob Licenca Creative Commons 